\title{
SYSTEMS OF FINANCIAL SUPPORT FOR IMPAIRED MINERS AND THEIR FAMILIES
}

When a working miner met with an injury or contracted a disease, perhaps the most pressing concern was how to survive the financial consequences. Impairment often necessitated a period of time away from work, or possibly the end of working life altogether. The loss of a weekly wage meant that the miner needed to draw upon one or more among a range of different sources of assistance. This chapter examines the various, changing ways that financial welfare was available in the late nineteenth century and the first half of the twentieth century. It considers various providers of assistance many of which dated from before 1880, such as charities, friendly societies and the Poor Law, in addition to the major developments in statutory systems of welfare which affected miners after that date. Such statutory interventions started with the Employers' Liability Act of 1880, continued with the Workmen's Compensation Act of 1897 (and several revisions in the decades after its introduction) and ended (as far as the scope of this volume is concerned) with the Industrial Injuries Act of 1946, which enshrined a generous system of benefits to injured workmen in the welfare state.

The years from 1880 to 1948 were a crucial time in the development of welfare in Britain. There was a gradual move from staunch adherence to individualism and the free market to greater state intervention in the 1880s and 1890s, and then more significant Liberal government reforms in the Edwardian period that for the first time enshrined in law the right to provisions such as school meals, pensions and health insurance. The interwar hiatus in legislation was followed by the post-war welfare settlement, which brought universal healthcare and finally abolished the individualistic and stigmatising Poor Law. These key details have formed milestones in the extensive literature on British welfare, ${ }^{1}$ and this narrative of progression can also be seen in the shifting depiction of welfare in coalfields literature across the time period. Broadly speaking, in 
the earlier Victorian and Edwardian novels there is a focus on paternalistic interventions by middle- and upper-class protagonists, framed in terms of Christian values and morally 'worthy' recipients. In the working-class realist literature of the interwar period ideas about welfare are couched in terms of rights and entitlements to fair workplace treatment and compensation, where the emphasis is more often on the (im)morality of political systems such as capitalism, rather than on the 'worthiness' of specific individuals. ${ }^{2}$ Yet, some historians have emphasised the problems with narratives based on the linear progression from individualism to collectivism, or from a paucity of provision to a 'new Jerusalem'. Jose Harris emphasises the complexity of the development of welfare, focusing instead on the 'piecemeal and unsystematic' series of policy changes that reflected the 'many counter-vailing social forces in a highly complex and diverse society. ${ }^{3}$ The varied experiences of miners may present something of a challenge to traditional narratives of welfare and the emergence of the social welfare state throughout the twentieth century. It is thus essential to take into account the lives and families affected by the changing legislative landscape.

Miners and their families, similar to workers and the poor elsewhere, drew upon a range of different providers in the mixed economy of welfare. Their choices, strategies and expedients varied from place to place and over time as resources waxed and waned, as their estimation of the social and cultural costs differed and as need and family circumstances exerted more or less pressure over time. Disabled miners were assisted in a variety of ways but they also suffered want, disappointment and desperation as providers failed to meet their needs or to sufficiently ameliorate the financial effects of disability.

\section{Family and community}

If the disabled person resided at the heart of a series of overlapping and interdependent nests of familial, community and social networks, then it was the family that was the closest, most intimate and most important source of support. ${ }^{4}$ The first thing a person did when faced with hardship, therefore, was to turn inwards and to draw upon the resources provided by the family. Savings would have been drawn upon and changes made to consumption patterns and, as is shown in the next chapter on social relations, different members of the family looked to enter the world of work in order to make good any shortfall in the income of the breadwinner. Such strategies and changes were important, but could help to only a limited degree and, sooner or later, impaired miners and their families were required to look beyond the immediate family and seek support from others. 
Collections or other fund-raising activities, often initiated in workplaces but extended into the broader community, were often used to raise a sum of money to assist injured miners. This could, at times, become a little more formalised. At Llwydcoed, near Aberdare, in 1898, for example, a 'benevolent prize drawing' was held to raise funds for David Hopkin, a miner with a large family who had been unable to work for the previous eighteen months as a result of an accident and would be unlikely to work again. The drawing was arranged by a small committee of his friends and fellow workers who drew up leaflets setting out his case, inserted appeals in the local newspaper and approached local elites, including the MP, for support. ${ }^{5}$

These community efforts, often referred to as 'lifts', figure prominently in coalfields literature, as authors utilised them to convey the close-knit character of mining communities. In the Welsh-language novel by T. Rowland Hughes, ${ }^{6}$ William Jones (1944), such a 'lift' is described by a miner visiting an ex-miner friend dying prematurely from silicosis:

Ôdd rhai'n cal 'u dewis bob Sadwrn pae i gasglu arian i helpu rhywun tost ne' withwr'di cal anaf yn y pwll, a fe welas i ddynon yn gwitho dyblar er mwyn rhoi arian un shifft i fachan yn ffaelu. ${ }^{?}$

Some were bein' chosen ev'ry Pay Saturday to collect money to 'elp somebody 'oo was bad or a workman 'oo'd 'ad an accident in the pit, and I' seen men workin' a doubler so as to give the money for one shift to a man not able to work. ${ }^{8}$

In Scottish miner and Labour MP James Welsh's historical novel, The Underworld: The Story of Robert Sinclair, Miner (1920), a manager tries to stop 'lifts' of money because he thinks it encourages men to stay off work, so he spreads rumours that the family have plenty of money. A collection is made anyway by a miner who says he can risk losing his own job over his principles and frames his actions as a point of freedom and moral principle against the manager's accusations. He ensures that the money and some tobacco are given without infringing on the dignity and pride of the family:

'It disna matter ... I dinna care though they had thousan's. What I don't like is this "ye'll-no-do-this-an'-ye'll-no-do-that" sort o' thing. What the hell right has ony gaffer wi' what a man does? It's a' one to him what I do. I'm nae slave, an' forby, I dinna believe they are weel-aff. They maun be hard up.'

The lift is a moral and political litmus test. In contrast to the "the "belly-crawlers" ... who "kept in" with the management by carrying tales, and generally acting as traitors to the other men, ${ }^{10}$ the rest of the community have defied the manager in solidarity with the injured worker. This becomes a catalyst for unionisation and is associated with Scottish pride. Providing financial support within the community for a disabled miner is therefore represented as a political act, one which looks forward to more organised welfare. 
Ultimately, however, family and community resources were finite, especially so in working-class communities such as those found in the coalfields, and the financial needs of disabled miners too often went unmet. The records of voluntary agencies that existed to provide welfare in coalfield communities are full of appeals for assistance from miners who found that they could not rely on familial and community resources alone. This was recognised, for example, by the Northern Coalfields Committee for their Special Emergency Grants in 1929:

In certain cases where a member of a family is confined to the house by sickness or accident, acute distress may occasionally ensue. The normal insurance and/ or compensation payments received during such periods must generally be regarded as sufficient mitigation of the resulting conditions, but exceptional cases may arise where assistance from the Fund would be a very real help. ${ }^{11}$

The Fund, therefore, was positioned as a last resort, a source of 'very real help' to those who had exhausted other avenues of support. The mining cases relieved by the Swansea Hospital Ladies Samaritan Funds were also framed as a support for vulnerable family care. An injured Dunvant collier, who had received no compensation and 'was the sole support of his mother' received $2 \mathrm{~s}$. $6 \mathrm{~d}$. a week from the Funds. ${ }^{12}$

In the same way, the statutory system of workmen's compensation took family circumstances into account in setting compensation payments to disabled miners. The Scottish Coal Workers' Compensation Scheme, for example, regularly mentioned family situations in its proceedings. John Black, a 38-year-old 'onearmed man' who also had his right leg broken in the pit was awarded a lump sum of up to $£ 250$ just before the First World War, the largest compensation recorded in the minutes. This decision was undoubtedly informed by the fact that 'he is a widower without family and lives in lodgings', likely an implicit acknowledgement of women's unpaid labour. ${ }^{13}$ Similarly, pony-putter Robert Henderson in Durham was awarded $£ 100$ after losing part of his thumb and two fingers - despite not being able to prove it was in the 'course of employment' - 'as there were some sad features connected with the case. ${ }^{14}$ This attests less to the generosity of compensation committees - others with 'sad features' were no doubt rejected - than to the absence of family and community support available to some miners.

\section{The voluntary sphere: self-help, mutualism and charity}

While the family and the community were the most important providers of welfare to disabled miners, in terms of both the amount of assistance provided 
and its place in the miner's life, it was inadequate to meet the needs of many miners and their families. ${ }^{15}$ Considerable strain was placed on working-class families by sickness and impairment, and too often the resources at their disposal proved inadequate to meet the considerable need that existed. In such instances, miners and their families were forced to look for assistance beyond the immediate family or community in order to supplement the care provided within the home. While mining communities had fewer voluntary resources than more affluent communities, still the types of voluntary welfare available to miners were numerous and ranged from self-help and mutualist forms to charitable and paternalistic provision.

Charities were numerous and varied in character across British communities and it is possible to discern some that were crucially important to mining communities and to the support of impaired miners. Blind and deaf charities, for example, were numerous in coalfield districts. For instance, the Cambrian Institution for the Deaf and Dumb in Swansea operated a 'Wonderful Penny' fundraising scheme, starting in the 1860s, in which workers from local collieries - alongside iron, copper and tinworks - donated a penny from their wages to the institution, many of whose pupils came from mining families. ${ }^{16}$ Another, the Rhondda Institution for the Blind, opened immediately after the 1920 Blind Persons Act which made it the duty of councils to provide welfare for blind people. ${ }^{17}$ Enshrined in the 'Conditions of Service' was the guarantee that 'A vacant place shall always be kept in the Workshops for any emergency that might arise with blind Miners or their dependents. ${ }^{18}$ As it was a mining area, many of those who received accommodation and participated in the workshops - which, like many other contemporary blind institutions, were focused on employment and manufacturing objects - came from mining families. ${ }^{19}$ Opinions regarding miners' work in the institution were clearly mixed, as seen in a letter from the National League of the Blind regarding a young blind miner in the institution who was 'anxious to be trained as a telephonist', the contents of which were 'rather scathing. ${ }^{20}$

Likewise, particularly in south Wales, institutions interacted with mining organisations, and local collieries regularly donated to blind and deaf institutions. The Rhondda Institution both met with the Executive Council of the South Wales Miners' Federation and the local miners' lodge and also received money quotas from colliery companies, though these were sometimes delayed or unpaid. ${ }^{21}$ Occasionally, this dealing with the coalfields intersected directly with the economic rehabilitation work offered in the Rhondda Institution, as is seen when the Ocean Coal Company ordered fifty coal baskets made by residents of the Institution in $1927 .{ }^{22}$ Local blind and deaf institutions were clearly seen by many as integral parts of the coalfield community. 
Friendly societies, run most often by and for miners, were as numerous as charities and were a key form of voluntary welfare for impaired miners, though their self-help and mutualist character marked them out as different to charities. The friendly society movement originated, to all intents and purposes, in the second half of the eighteenth century and, from the 1790s onwards, gained an increasing degree of legal recognition and protection as the state put aside its initial fears and recognised the important contributions that societies could make to thrift, respectability and financial self-sufficiency. The movement grew in size in the early decades of the nineteenth century, especially in the $1840 \mathrm{~s}$ as the Poor Law Amendment Act gave a boost to efforts by working-class families to remain beyond the clutches of the hated workhouse. It was also from that decade that the affiliated orders came to prominence, and societies such as the Oddfellows, the Foresters and the Shepherds spread the actuarial risks posed by sickness and death more broadly through enlisting large numbers in membership across their numerous lodges. ${ }^{23}$

Miners' engagement with friendly societies came in different forms. It is possible to discern many societies or lodges the majority of whose members were employed in the coal industry, perhaps even at the same colliery, or else who all derived from the same occupational group within the industry. In an example of the latter, in the early twentieth century the Durham County Colliery Enginemen's, Boiler Minders' and Firemen's Mutual Aid Association and National Insurance Approved Society offered its members both sickness benefits for up to 26 weeks and disablement benefits after sickness benefit had finished, though only after impaired members had been insured for 104 weeks and also paid the same number of weekly contributions. ${ }^{24}$ In other instances, miners were explicitly excluded from membership of some societies. The 1885 rules of the Tradesmen's Annual Friendly Society in Shotton, County Durham, for example, listed miners alongside 'loiterers, idle persons, soldiers or sailors' as those unable to join. ${ }^{25}$ This perhaps reflected a certain class prejudice, as better-skilled workers or members of the petit bourgeoisie looked unfavourably on miners as an occupational group; but it also constituted a recognition of the relatively dangerous nature of coalmining and the bad risk that miners' high rates of injury and sickness posed to the actuarial soundness of friendly societies. ${ }^{26}$

This actuarial fragility also gave rise to a number of other distinctive features that were characteristic of friendly societies and that had particular consequences for disabled miners. In the first place, careful to protect their slender resources, friendly societies placed quite strict conditions on membership, the chief of which was that potential members were required to disclose any health issues and were denied entry into the organisation if they were considered a likely bad risk. One of the rules of the Aberaman Colliery Friendly Society, for example, 
stated that 'No person shall become a member of this Society who is of unsound health, or suffering from any chronic or other disease', and such conditions of membership were universal across the movement. ${ }^{27}$ This society forced members who were found to be 'not healthy' after initiation to forfeit their money and leave the society; many others imposed fines. ${ }^{28}$ The Llanbradach Colliery Sick Benefit Society added a new rule in 1905 that benefits to any member would cease, should it be found that the claimant was 'afflicted with any disease prior to his becoming a member. ${ }^{29}$ As such, miners who were already impaired, whether by injury or illness, found it impossible to join a friendly society and to protect themselves against further impairment.

Upon experiencing a disabling injury or condition, friendly society members were monitored by the lay officers or other members of the society. The Durham County Colliery Enginemen's, Boiler Minders' and Firemen's Mutual Aid Association's rules required that members of the Association drawing sickness or disablement benefits had to send a medical certificate 'or other sufficient evidence of incapacity for work' to the secretary once every two weeks and, potentially, also submit to a medical examination. The Glais Benefit Society, near Swansea, employed dedicated sick visitors whose duty was to 'visit the sick within three days after receiving notice', and at least a fortnight after that. The sick visitor faced a fine for not performing the duty, and could be replaced by stewards for repeated failure to perform. This suggests that friendly society officials wanted to demonstrate how seriously their societies took the threat of abuse of benefits or 'malingering. ${ }^{30}$

In addition, benefits were disallowed if the claimant were to supposedly 'bring upon himself sickness or lameness' by 'fighting, leaping, running, footballing, or any other acts of bravado, or immorality. ${ }^{31}$ Any benefits paid by friendly societies as a result of impairment were therefore framed and monitored from both a medical and moral viewpoint, and observed with close attention to the financial position of the particular society. Miners on the funds were monitored closely to ensure that the impairment was genuine and that the miner was not 'malingering', and also that they behaved in a moderate and respectable manner. At the same time, it should perhaps be noted that words such as 'brotherhood', 'fraternity' and 'mutualism' littered friendly society materials and, given the numerous examples of inclusive and generous treatment, this was more than mere rhetoric. These visits served to emphasise those very values and fraternity extended to disabled miners, who were not subject to any greater scrutiny than any other individual in receipt of sickness benefits. The North Eastern Counties Friendly Societies Convalescent Home elaborated on this in 1888: 'This scheme gives to the working classes an opportunity of showing to the world that they are mindful to the weak and sick ones amongst them. ${ }^{32}$ 
Friendly societies merged their functions as mutual aid with their position as social gatherings of miners. The annual dinner and weekly or monthly club night functioned as key social events on miners' calendars, in addition to being spaces to collect their funds. Not all approved, however. Concern about the moral implications of this form of financial aid, that is, that it promoted malingering or dependency, was expressed in the Methodist-influenced coalfields novel Rhoda Roberts: A Welsh mining story (1895) through the device of showing the weekly collection being held in a pub. The men go in 'clean, bright and sober, to go to pay their contributions at the [Garter Sick and Benefit Society]' and emerge 'dull-eyed, heavy, filthy, and drunken., ${ }^{33}$

Friendly societies were occasionally granted moral, practical and even financial support by employers, particularly in the earlier part of the nineteenth century, but they were nevertheless working-class organisations. Committees of working men administered the movement at a local level and drew upon working-class values and priorities in the decisions they made. In contrast, many permanent provident funds similarly relieved miners on account of 'disablement' but were funded and administered through the efforts of workers and employers working in conjunction with each other. Permanent relief funds were established on a coalfield-by-coalfield basis during the second half of the nineteenth century, with constituent branches or 'agencies' at each colliery that joined the movement. They were funded by worker subscriptions and employer donations, the precise proportions varying from coalfield to coalfield, and paid death benefits to the families of miners killed in workplace accidents. ${ }^{34}$

The first society, the Northumberland and Durham Miners' Permanent Relief Fund, was initiated in 1862 after the Hartley Colliery disaster of the same year which killed 204 people. ${ }^{35}$ Other coalfields emulated Northumberland and Durham and founded their own permanent relief funds in the decades that followed: a society for North Staffordshire was founded in 1869, Lancashire and Cheshire in 1873, followed by Yorkshire in 1877 and south Wales in $1881 .^{36}$ The critical role of Hartley in the history of relief funds is recorded in Durham miner Harold Heslop's historical novel The Earth Beneath (1946), in which he dedicates a chapter to the Hartley disaster. Heslop argues that Hartley was the event that changed the way that miners portrayed themselves, a great catalyst for political discourse in which miners 'were beginning to dramatise themselves and their surroundings; their role was that of the maligned creature of injustice. ${ }^{37}$

While the first such permanent relief society was established in the wake of this large disaster, the movement as a whole came to place attention not on large-scale losses of life but, rather, on the smaller incidents that took one or two lives at a time. As supporters of the movement pointed out, the numbers of lives lost to small-scale accidents in which no more than a few men were 
killed at a time far outstripped the death tolls caused by explosions, falls and inundations in which hundreds were killed. ${ }^{38}$ Such 'disasters by instalment', as the small accidents were characterised in the permanent provident fund movement, did not elicit the same public sympathy or, crucially, donations as the larger disasters, and the widows and 'orphans' of the men killed were left with little effective support. Crucially, the Northumberland and Durham Miners' Permanent Relief Fund drew upon an older tradition of 'smart money' paid by employers to injured workers in the North-East coalfield and instituted a system of 'disablement' benefits in 1863 by which miners incapacitated by accident were paid a sum of money while they were unable to work. ${ }^{39}$ Henry Baker was the first claimant on the permanent disablement fund and received benefit from January 1863 until his death in March $1875 .^{40}$ Other miners' permanent provident funds also paid disablement benefits in the decades that followed.

By the 1890s disablement benefits paid by the different permanent relief funds varied from 5 s. to 10 s. a week. ${ }^{41}$ Northumberland and Durham paid $5 \mathrm{~s}$. a week to members disabled from working for periods under twenty-six weeks, the payments increasing to $7 \mathrm{~s}$. after the worker had been off for more than twenty-six weeks. This increase stands in contrast to the practice of friendly societies, where the level of payments decreased over time. ${ }^{42}$ In contrast, Monmouthshire and South Wales Miners' Permanent Provident Society paid 8 s. a week in disablement cases and did so indefinitely, without any reduction over time, but this was reduced to 6s. in $1902 .{ }^{43}$ Benson has found, through analysis of the records of the permanent relief funds for Lancashire and Cheshire and for the West Riding of Yorkshire, that miners in receipt of disablement benefit in the late nineteenth century were off work for an average of around six weeks. ${ }^{44}$

The payment of these disablement benefits was one of the greatest challenges faced by the management boards of the funds, as many found that the payments accounted for a significant and growing proportion of their expenditure in the late nineteenth century. This, in turn, caused tension between workmen's representatives and those individuals more closely aligned with the interests of employers as pressure came to be exerted on claimants as a means to control expenditure. ${ }^{45}$ This varied in extent from coalfield to coalfield as accident and disablement rates varied.

The board of the south Wales society noted the large number of disablement cases in 1885, for example, when it was observed that while there had been seventy-five deaths in the year up to March 1885, there were 6,207 disablement cases. ${ }^{46}$ As a result, all disablement cases of more than twenty-six weeks' standing were investigated and, while very little 'malingering' was found, payments were reduced in many cases, seemingly on financial grounds alone. ${ }^{47}$ 
Table 1 Disablement cases and rates for certain miners' permanent provident funds, $1885-90$

\begin{tabular}{|c|c|c|c|c|}
\hline & & $\begin{array}{l}\text { Northumberland } \\
\text { and Durham }\end{array}$ & $\begin{array}{l}\text { Lancashire and } \\
\text { Cheshire }\end{array}$ & $\begin{array}{l}\text { South } \\
\text { Wales }\end{array}$ \\
\hline \multirow[t]{2}{*}{1885} & Cases & 14,924 & 7,054 & 7,805 \\
\hline & Rate per 100 members & 17.2 & 18.5 & 20.8 \\
\hline \multirow[t]{2}{*}{1886} & Cases & 11,544 & 7,348 & 9,795 \\
\hline & Rate per 100 members & $?$ & 18.1 & 23.8 \\
\hline \multirow[t]{2}{*}{1887} & Cases & 14,409 & 7,409 & 10,801 \\
\hline & Rate per 100 members & 15.7 & 17.9 & 25.6 \\
\hline \multirow[t]{2}{*}{1888} & Cases & 15,700 & 7,870 & 9,020 \\
\hline & Rate per 100 members & 16.5 & 18.5 & 22.9 \\
\hline \multirow[t]{2}{*}{1889} & Cases & 16,000 & 7,921 & 10,985 \\
\hline & Rate per 100 members & 16.0 & 17.7 & 23.9 \\
\hline \multirow[t]{2}{*}{1890} & Cases & 16,000 & 7,524 & 10,164 \\
\hline & Rate per 100 members & 14.8 & 15.2 & 19.2 \\
\hline
\end{tabular}

Source: Campbell, Miners' Thrift and Employers' Liability, Appendix A, Table H.

The fears of ever-increasing disablement payments often led to a similar policing of impaired claimants as that seen in the friendly societies. The 1899 rules of the Northumberland and Durham Miners' Permanent Relief Fund offered a 'fixed lump sum' for impairment, but this was subject to several conditions: applications had to be made within thirty-five days of the accident, a medical certificate had to be provided, there were visits by the Visitation Committee and the applicant had to be 'desirous of making an effort to help himself'. Added to this, claimants must not be 'trying work' after an accident. ${ }^{48}$ The committee minutes demonstrate that these rules were regularly enforced, clearly with an eye on saving money on the costs of payment for impairment. One miner's benefits were suspended in 1906 'until he puts himself in order with the rules and makes a new application. ${ }^{49}$ The south Wales fund had similar policies, and in 1884 asked for the 'vigilance of the local officers' to make sure accidents 'have actually happened in connection with colliery working, and that they are duly vouched for by surgeons. ${ }^{50}$

The relief funds were a crucial source of income for many impaired miners. The large numbers of miners who joined the societies demonstrate the worth that miners perceived in the societies' activities, while the significant numbers who received disablement benefits show the wisdom of that perception. Nevertheless, the permanent provident societies varied in the extent to which 
they enlisted miners in their coalfields in membership, with degrees of coverage varying from roughly 90 per cent in the 1890s in the north-east of England to between 5 and 10 per cent in south Wales in the Edwardian period, and so they varied also in the degree to which they met the needs of disabled miners in the respective coalfields. ${ }^{51}$ In addition, Benson is correct to stress the collaboration that existed at the heart of the societies, but the quality and extent of that collaboration varied from coalfield to coalfield. The fund in the more consensual north-east of England continued as a viable concern into the 1930s and beyond, while its counterpart in the more combustible south Wales coalfield lost almost two-thirds of its members in the wake of the 1897 Workmen's Compensation Act and was largely defunct by $1906 .^{52}$ As such, the permanent provident society movement was never more than a partial solution to the financial problems caused by miners' impairments. Given the impossibiliy of family or community meeting the needs of impaired miners, and as the myriad of organisations and bodies in the voluntary sphere failed to prevent the considerable poverty that existed, many miners were forced to look to other sources of relief. Increasingly during the late nineteenth and early twentieth centuries this often meant the state and, in particular, the Poor Law, a flawed and stigmatising system that was despised by miners as much as by other workers.

\section{Public provision for disabled miners: the Poor Law}

From 1880 until its eventual disappearance in the twentieth century, the Poor Law played a complex role in the provision of assistance to disabled people in mining communities. Many viewed it as an option of last resort and it was often used only in times of crisis or destitution. For miners, similar to the population more generally, the Poor Law was one among a number of welfare providers and was drawn upon to supplement other forms of relief and benefit. The Poor Law is crucial to the history of disability in the nineteenth and early twentieth centuries. It set out the ideals and limitations which defined poverty and disability, and created a discourse of who was 'deserving' of welfare. The Poor Law Amendment Act of 1834 introduced the principle of 'less eligibility', which aimed to make relief as undesirable as possible and made the imposing and oppressive workhouse as much of a deterrent to the supposed problem of dependency as possible. The situation of the pauper, wrote the Commissioners of 1834, 'shall not be made really or apparently so eligible as the situation of the independent labourer of the lowest class. ${ }^{53}$ The 1834 Amendment Act's configuration of poverty as an individual and moral concern, many historians have argued, was a key ideological tenet throughout the Poor Law's life. ${ }^{54}$ This served to create a statutory distinction between the 'deserving' and 'undeserving' 
poor, with disability often playing a key role in who was considered deserving of relief.

Deborah Stone's work contends that the New Poor Law was a powerful and influential factor in the conception of disability in the nineteenth century, and points out that the categories of pauper outlined in the 1834 Poor Law Amendment Act form part of modern conceptions and lexicons of disability: the 'sick', 'insane', 'defectives' and the 'aged and infirm' were positioned as separate categories with different levels of eligibility for relief or potential for fraud. ${ }^{55}$ Stone describes their position within the Poor Laws as a supposed economic 'distributive dilemma' facing Poor Law administrators, in which welfare could be offered to deserving applicants so as to 'reconcile the distributive principles of work and need without undermining the productive side of the economy. ${ }^{56}$ Historians have seen these modes of categorisation as creating a long-lasting effect of pauperisation on disabled people. Anne Borsay describes the Poor Law, regardless of its initial intentions, as 'delivered through a system designed to stigmatize applicants without work and exclude them from the community. ${ }^{57}$ Furthermore, David Turner argues that the 1834 Act - along with contemporary media and other discourses - helped to propagate the long-running narrative of the 'fraudulent' disabled claimant of welfare, which continues to this day. ${ }^{58}$ The Poor Law is commonly criticised in literature, which nevertheless adopts the discourse of the deserving poor, forced into penury through no fault of their own via disability and the failings of Poor Law. In The Black Diamond (1880), a miner's widow, who has been doing needlework to get by, loses her income through arthritis:

How pitiable it is that the paralysis of one right hand will reduce, in the midst of our Christian society, a family from comfort and respectability, to beggary and misery. There is a great work yet to be done by some Christian philanthropist - a work that will supersede our clumsy inhuman Poor Law, with it prison-like workhouse, and police-like officials - which will not treat the widow and the orphan as criminals, but will provide for their necessities and take their part. ${ }^{59}$

The author was a Primitive Methodist Minister, which perhaps explains this vision of welfare in terms of Christian paternalism rather than state intervention. Elsewhere within coalfields literature the Poor Law, or parish relief, is used as a device to explore the politics of poverty, unemployment and industrial action. In 1929, Durham miner Harold Heslop argued that the cultural significance of receiving the "mean charity ${ }^{60}$ of the Poor Law was changing in an age of industrial action (particularly the 1926 General Strike and lockout):

Instead of the debt to the Guardians being regarded as a mark of shame, as in the old days, it was now a token of having suffered. Poor Law Relief, in these days 
of clashing forces, assumed the aspect of sanctity. The relieving officers became the new historians, writing the histories of the workers, not in the books of a trade union, but in the ledgers bound in leather, with the quills of calm charity. ${ }^{61}$

The change in perception is how the applicant feels about receiving relief, rather than any change to the way the money is administered or Boards of Guardians treat applicants. In this way, coalfields literature illustrates both the unease felt about drawing upon poor relief - in large part because of the way that applicants were treated - and that stigmatisation was mitigated during times of industrial action because of an underlying political purpose that justified a period of worklessness and financial hardship.

The Poor Law undoubtedly carried a social stigma and was likely regarded by most as an emergency of last resort when one met with injury or disease: 'To be a pauper was the great danger to be avoided, and hell itself held no terrors greater than that for the bulk of them,' wrote Scottish miner, novelist and Labour MP James Welsh in $1924 .{ }^{62}$ Reliance on the Poor Law in old age was particularly dreaded. Another Scottish miner, Tom Hanlin, who became a writer while convalescing from a mining injury, portrays a miner's widow with consumption fading away from the toil of widowhood, including 'telling your life story to a hard face in a parish office. ${ }^{63}$ These negative connotations are confirmed in the memoirs of the Welsh labour activist Elizabeth Andrews, who recalled that 'Many sickness clubs were formed in those days in the mining areas ... There was a real dread of being buried by the Poor Law in a pauper's grave. ${ }^{64}$ Andrews' words, reinforced in coalfields fiction, illustrate the need for miners to utilise multiple forms of welfare so as to avoid the destitution that threatened to come with sickness or disability.

Despite its continued presence in the literature of the time, the period 1880-1948 saw the gradual decline of the Poor Law as the state increasingly recognised the need for other, wider forms of assistance and began to attribute poverty to environmental and structural causes rather than moral and individual failings. In particular, the reforms carried out by the Liberal government between 1906 and 1911 saw the architects of welfare policy acknowledging the need for a shift away from the individualism of the nineteenth century and towards a more collective provision for certain groups within the population. As a result, several changes occurred during the first half of the twentieth century that weakened the influence of the Poor Law: the Ministry of Health was created in 1919 and assumed responsibility for the Poor Law, with the original Boards of Guardians still overseeing local administration. ${ }^{65}$ More significantly, the 1929 Local Government Act abolished the Boards of Guardians, to some protest by their members, and transferred the Poor Law administration to the Public 
Assistance Committees of individual counties and county boroughs. ${ }^{66}$ This signalled the final decline of the Poor Law until its functions were taken over entirely by the welfare state in 1948 . Thus, any disabled miners who claimed poor relief in the period from 1880 to 1948 did so within a changing administrative and policy context, and one in which regional variations in practice and generosity determined the character of their experiences. ${ }^{67}$

Having exhausted any familial, community, self-help or mutualist sources of support that might have been available, disabled miners made application to relieving officers for assistance under the Poor Law to relieve the effects of poverty caused by impairment. The vast majority of such miners would have been relieved outside the walls of the workhouse and were made cash payments, or else were granted other forms of assistance in their homes. The proportions of relief given in indoor or outdoor forms varied from one Poor Law union to another and from region to region, but it is clear that the workhouse was not the experience of most paupers (disabled or not) in the late nineteenth century. A return for $1887-88$ found that 70 per cent of all relief distributed in Durham was given in the form of out-relief, or 'domiciliary' relief, while the corresponding figure for 'South Wales' was 83 per cent; the average for England and Wales at the time was 59 per cent. ${ }^{68}$ The figure was greater again in Scotland as a result of the lower level of institutional provision under its separate Poor Law system, partly determined by the poverty of the country's communities. ${ }^{69}$ By the mid-1930s the proportion for England and Wales stood at 87 per cent, while that for Scotland was as high as 94 per cent. ${ }^{70}$ Thus, disabled miners tended to receive domiciliary relief rather than to be relieved in the workhouse.

The "mean charity" ${ }^{\text {"11 }}$ of the Poor Law, it is clear, could provide an important resource for miners in their attempts to deal with disability. Lists of applications for relief presented by Carluke miners in the late nineteenth century featured several individuals claiming relief for rheumatism, bronchitis and broken or diseased legs, and there were a variety of outcomes. In the case of Andrew McAllister, a twenty-seven-year-old miner from Douglas, Lanarkshire, 6s. a week was granted in 1885 due to his incapacity to work following the amputation of a foot. John Gardiner, a twenty-six-year-old miner from the same parish with a wife and four dependent children, was similarly granted 6 s. a week after being confined to his bed by an injury for ten months. ${ }^{72}$ In neither case would 6 s. have been enough to sustain their families, and the men would have had to seek additional assistance if their injuries were not to cause dire poverty for themselves and their families. These records demonstrate that miners used the Poor Law as a source of relief in conjunction with other agencies: in Govan parish in 1896 one collier was listed as 'wholly disabled' for two weeks from a 
bruised knee, and was granted outdoor relief alongside his relief from Dickson's Society and the Works Society. ${ }^{73}$

These cases from Carluke demonstrate the tendency for miners with disabling injuries to seek relief from the Poor Law authorities, but it is evident that occupational disease was also the cause of a great deal of poor relief granted to miners: again, records relating to the Poor Law in Carluke, Lanarkshire in the 1890s demonstrate a large number of miners relieved as a result of 'miners' asthma' or 'congestion of the lungs. ${ }^{, 74}$ Decades later, impaired miners continued to turn to the Poor Law for assistance. In a particularly revealing case from Bedwellty Union, south Wales, in 1924 that highlights the difficulty of negotiating the compensation system and how it could force miners to turn to the Poor Law, the relieving officer strongly urged the Board of Guardians to relieve a thirty-one-year-old miner with a wife and eleven dependent children who had previously been in receipt of 35s. a week in compensation payments as a result of nystagmus. The miner had resumed 'light employment' at Markham Colliery some time after his compensation award but the Tredegar Iron and Coal Company then suspended his compensation and he now suffered 'insufficient means'; the relieving officer described him as a 'very deserving case. ${ }^{75}$ Apart from such dole payments, Poor Law authorities also provided relief in kind to impaired miners: blankets, bedclothes, boots, clothing and foodstuffs were just some of the forms of relief granted to miners and their families. $^{76}$

While out-relief was the most common form of assistance to disabled miners, some nevertheless tended to end up within the walls of the hated workhouse. It is evident that the workhouse test was applied in some cases to measure a disabled applicant's eligibility for relief. ${ }^{77}$ In the case of Pontypool workhouse in south Wales in the 1880s, miners there listed as 'able-bodied' were often admitted with conditions such as facial paralysis, disease or 'dropsy' and appeared to use the workhouse's medical facilities to recover. Colliers listed as 'old/infirm' tended to be in their fifties or sixties and were listed with conditions such as asthma, rheumatism or, in one case, blindness. Many were 'discharged at [their] own request', suggesting that the workhouse was treated as a last resort in times of personal financial trouble or sickness. ${ }^{78}$ Disabled miners used the workhouse when necessary, but were not necessarily bound there permanently.

While sick and disabled individuals were classed as deserving under the Poor Law system and were granted relief more readily than the 'able-bodied' poor, still there was concern that the potential existed for false claims and 'malingering'. Inspectors regularly exhibited a sense of distrust and reluctance when administering Poor Law relief to disabled people, and extensive 
documentation was often required before relief was granted. In 1910 the Easington Union Committee in Durham noted that a miner had a 'personal application made by his wife' that he was suffering from rheumatism. Though he successfully received weekly relief, he was 'requested to produce a medical certificate before any relief was paid and over [sic] and also a medical certificate each week', signed by the doctor of the local colliery. In this case it was reported that the man 'came to [the Committee member's] farm to beg and on questioning him had admitted that there had never been, nor was there at the present time, anything the matter with him. ${ }^{79}$ This sceptical attitude was not uncommon elsewhere. The Glasgow Herald in December 1911 reported that a man was charged of 'falsely representing that he had sustained an accident at Dechmont Colliery ... and was unable to work and required temporary ailment [sic aliment] for himself and his family. ${ }^{80}$ Many suspicious individual cases were reported and dissected in the media, contributing to a climate of fear about potential fraud.

In addition, Poor Law officials were careful to ensure that the support received by miners from friendly societies or other welfare programmes was taken into consideration when granting relief. Assessments of need by relieving officers meant that all sources of income were accounted for before the decision to relieve was made. John Benson has studied the extent to which different Boards of Guardians considered friendly society benefits in their assessments of need and has noted that they were able to disregard friendly society payments of up to 5 s. a week from 1894 onwards. The difficult circumstances of the lockout in 1926, with pressure from the central Poor Law authorities to exercise caution in the granting of relief, meant that Poor Law Unions varied in their inclusion of friendly society benefits in assessments but did nevertheless lessen relief payments according to any additional income from that source. ${ }^{81}$ Such assessments of additional sources of income carried on into the 1930s. In 1935 the Northumberland Public Assistance Committee discussed whether the Miners' Permanent Relief Fund counted as a friendly society within the Poor Law, and amended the county's outdoor relief regulations to assert that,

In granting outdoor relief to a member of a Friendly Society or to a person entitled to receive any benefit under the National Health Insurance Acts, the Guardians Committee shall not take into consideration any sum received from a Friendly Society as sick pay or any benefit under the National Health Insurance Acts, except so far as such sick pay or benefits exceeds $7 \mathrm{~s} 6 \mathrm{~d}$ per week. ${ }^{82}$

Thus, the Poor Law had a role, albeit a limited one, in a mixed economy of welfare for miners, most of whom saw it as a temporary measure. For some time before 1880, the Poor Law was the only available form of state welfare 
in this mix, but, beginning with the Employers' Liability Act of 1880, the state intervened to a greater extent to facilitate compensation for disabled miners.

\section{State intervention: the Employers' Liability Act 1880 and the Workmen's Compensation Act 1897}

The Employers' Liability Act of 1880 and the Workmen's Compensation Act of 1897 were to redefine the role of the state in the lives of disabled miners. They represented a growing awareness of the need for the state to intervene to ensure the payment of compensation and placed the onus of responsibility onto employers. The Acts made industrial injuries and disease compensation available to miners, but also brought with them all the difficulties of an adversarial legal system in which the extent or provenance of disability was disputed by employers who had a financial incentive to deny or lessen liability.

The Employers' Liability Act was passed in 1880 after a series of bills and Trade Union Congress petitions in the late 1870s, and the question of the liability of employers for accidents emerged as an issue in the 1879 general election. ${ }^{83}$ The Act enshrined in law for the first time the principle that workmen injured by a fault at their workplace - defects in conditions of machinery, the negligence of employers or superintendents - had a right to compensation. However, some employers were able to 'contract out' of the Act by making 'joint' provision with their workmen through the establishment of permanent provident funds that offered death and disablement benefits in place of any compensation that might have been secured through the legislation. ${ }^{84}$ Contracting out limited the scope of the Act to some degree, but it was other flaws that were most to blame for its rather toothless nature. This has led the leading historian of the legislation to describe it as 'a minor adjustment to, rather than a revolution in, liability law. ${ }^{85}$

Such was the flawed nature of the 1880 Act that a great many efforts were made through the 1880 s and 1890 s to amend it. Different interests advocated a series of changes to the legislation, including variously the abolition or retention of contracting out, and a number of different bills were presented in Parliament. Ultimately, Joseph Chamberlain passed the Workmen's Compensation Act of 1897, which superseded the Employers' Liability legislation, and the measure made employers liable to pay compensation for any personal injury 'arising out of and [which] in the course of the employment is caused to a workman'. According to Bartrip, injured workers were now established as 'an elite group, analogous to war pensioners, eligible for special benefits denied to other, perhaps similarly injured, members of society. ${ }^{.86}$ 
Contracting out continued to be a possibility under the new legislation and helps to explain the significant differences in practice and experience in the various coalfields. The Northumberland and Durham Miners' Permanent Relief Fund continued as a viable concern into the mid-twentieth century and continued to tailor its activities to the changing compensation landscape: in 1938 it changed its rules to allow claimants with diseases such as nystagmus, compensatable under the Workmen's Compensation Act, to claim. ${ }^{87}$ Contracting out continued in south Wales but was far more controversial and came to be challenged increasingly by the labour movement. Keir Hardie, the Scottish miners' leader and subsequently MP for Merthyr Tydfil, castigated the coalowners in south Wales for the arrangement by which they paid 25 per cent of the workers' contributions: 'The outcome is a death and disablement rate which entitles Wales to be regarded as the slaughterhouse of the coalfields of the kingdom.' He continued, 'In their haste to be rich mineowners seem to regard human life as the cheapest of all commodities. ${ }^{88}$ The result of this politicisation was that, in contrast to the north-east of England, miners abandoned the Permanent Provident Society after the 1897 Act was passed: membership more than halved from 1897 to 1898 and was dealt a further blow with changes to the legislation in 1906 , such that there were fewer than 1,000 members by $1907 .{ }^{89}$

The workmen's compensation system underwent further revision in the years that followed, largely as a result of the changing nature of medical and scientific knowledge, but also as a result of trade union pressure. Many of these changes were devoted to scheduling miners' diseases and conditions as compensatable under the Act, including silicosis, nystagmus, pneumoconiosis and beat knee and elbow. Others changes were responses to major events and the changing economic situation, such as the 1917 and 1919 Workmen's Compensation (War Addition) Acts, which increased compensation for 'total disablement' and responded to the increased costs of living brought on by the war and the impact of this on disabled people. ${ }^{90}$ Workmen's compensation was eventually criticised for its separate administration from other forms of welfare in William Beveridge's Social Insurance and Allied Services, and the final 1945 Royal Commission on Workmen's Compensation failed to report, signalling its replacement by the post-war welfare state. ${ }^{91}$ The system was again radically overhauled in the $1940 \mathrm{~s}$ with the passage of the Industrial Injuries Act in 1946, which socialised the costs of industrial injury, thus making the injured miner a cost on the state rather than one to be borne by private enterprise.

The Employers' Liability Act of 1880 and the Workmen's Compensation Act of 1897 brought employers and workers into dialogue with each other in relation to disability as never before, but also created new sources of contention and conflict. Although the right to compensation was guaranteed in both the 
Employers' Liability Act and the workmen's compensation legislation, the process of making a claim and securing compensation was beset by delays, difficulties and anxiety for disabled miners. When meeting with accident or illness, miners were required to notify their employer of the issue. This would usually result in a medical examination of the miner by a doctor appointed by the colliery company. If the doctor attested to the presence and extent of the impairment, a sum of compensation would be paid to the miner, either in the form of a weekly payment or else as a lump sum. Where the colliery company disputed the causation or extent of the impairment, a miner had recourse to take his case through the court system, where, in an adversarial context, medical experts could be called, evidence presented by either side and a case made for compensation to be paid. Legal representation and medical testimony needed to be paid for, of course, and this was extremely difficult for any miner who did not have access to trade union resources. ${ }^{92}$

The extent to which this legal system was adversarial varied from one coalfield to another, depending on the nature of labour relations in those places. Labour relations were more combustible in south Wales and Scotland, with greater militancy on the part of trade unions and employers, and this was reflected in a great number of contested cases than in Durham, where a joint Arbitration Committee involved union and employer representatives in discussions over medical assessments and decisions on compensation payments. ${ }^{93}$ The miners' union there routinely started each meeting of the Committee by nominating the same coalowner to chair the meetings, such was the trust felt in him by both sides. ${ }^{94}$ Any decisions made by the Arbitration Committee were to be considered as binding on both parties as any decision given by a county court. It was stated in 1916 that such was this 'friendly arrangement between the representatives of the Durham Coal Owners and Miners in regard to the administration of the Workmen's Compensation Act' that 'costs are never asked for or paid, and verbal notice of an accident to a mine official is under certain circumstances accepted as sufficient by the Owner. ${ }^{95}$ Between 1898 and 1922 the Arbitration Committee dealt with over 5,000 cases. $^{96}$

Despite such cooperation, compensation continued to be a source of contention in the Durham coalfield and the miners' union reacted with anger at what they perceived to be efforts by the employers to harass disabled miners and minimise their compensation liabilities. In particular, the Durham Miners' Association found in the 1920 s that employers were allowed by the terms of the legislation to end compensation payments whenever they wished and require disabled miners and their union to take the case before a medical referee, the Arbitration Committee or the county court. Even where a medical referee decided in favour of the disabled miner, the employers could again stop payment 
almost immediately and require the miners to undergo a further examination, all the time saving on the payments that would otherwise be made to the miner. In contrast, a decision against the miner by the medical referee allowed little recourse to appeal and left the miner without any payment whatsoever. ${ }^{97}$ 'When the Owners proclaim a desire for better and more harmonious relationships between themselves and the miner', the Miners' Association stated, 'we could better appreciate their desire if they made it more manifest by their better treatment towards the injured.' 98

Joanna Bourke has noted that in the compensation court, the injured worker was customarily treated as though he were "on trial"' and the 'insurance doctors tended to be hostile to workers. ${ }^{99}$ Depictions of hostility between the doctor and compensation claimant are common in coalfields literature, where the encounter is often representative of wider class interests; the class allegiance of the doctor was seen to align with the interests of the coalowners and managers. ${ }^{100}$ In T. Rowland Hughes's novel William Jones, Crad, who has worked in both quarries and coal mines, has silicosis but does not get compensation:

'Mi apeliais am un. Mi es i lawr at y specialist yng Nghaerdydd ac wedyn o flaen y Board, ond 'doedd dim digon o lwch ar fy mrest i imi gal compo. Glywist ti'r fath lol yn dy fywyd? 'Taswn i'n medru mynd dan ddaer am ryw flwyddyn arall i gal tipyn chwanag o lwch tu mewn imi, mi gawn i gompensation - a charreg fedd! ${ }^{101}$

'I appealed for it. I went down to the specialist in Cardiff and before the Board after that, but there wasn't enough dust on my chest for me to get compo. Did you ever hear such nonsense in your life? If I had been able to go down below for a few more years to get a bit more dust inside me I would get compensation - and a gravestone! ${ }^{102}$

Coalfields literature very often focused on compensation for silicosis, in part because lung disease was very common, but receiving the diagnosis of silicosis, rather than bronchitis or tuberculosis, was also crucial to gaining compensation. ${ }^{103}$

The author's class allegiance clearly influenced the depiction of the medical gatekeeping of compensation, particularly as it related to the perception of malingering. A. J. Cronin, who had worked as a colliery doctor in south Wales and Medical Inspector of Mines, ${ }^{104}$ notes his personal suspicions of compensation claimants in his autobiography: 'my real invalids were numerous, but I had also to deal with the other sort ... many of the old time miners affected the symptoms of nystagmus and beat-knee, occupational diseases which entitled them to a pension. ${ }^{105}$ These suspicions influence a scene in The Citadel (1937), in which workers and the doctor clash over the denial of a compensation certificate to a long-time claimant. Ben Chenkin is claiming for nystagmus, but is portrayed as a malingerer: 'a great lump of a man, rolling in fat, who smelled strongly of 
beer and looked as if he had never done a full day's work in his life. ${ }^{\prime 106}$ The other 'compo cases' ${ }^{107}$ draw ranks against Dr Manson, withdrawing their cards and refusing to be treated by him. Within the novel this is portrayed as working-class stubbornness against their own best interest, in contrast to the scientifically sound and therefore objective judgement of the middle-class doctor.

The basic trajectory of a compensation claim was further complicated by other factors that caused problems for the disabled miner in his attempts to secure financial recompense. When a workman made a claim for compensation, the wait for any form of payment presented an immediate issue. The Employers' Liability Act of 1880 ensured that proceedings for compensation should be started within six months of injury, while the Workmen's Compensation Act of 1897 stipulated that injuries must 'disable the workman for a period of at least two weeks from earning full wages at the work at which he was employed. ${ }^{108}$ However, the actual experience of waiting for compensation could be much longer than this. This was the experience of the Welsh miner Bert Coombes, who wrote, 'I think I waited nearly a month before they started to pay anything ... They cannot seem to realise that most of us are living on our next week's wages, and that even a day out of that means that someone must go short.' ${ }^{109}$

Those that did have to 'go short' while they were waiting for the administrative process of compensation had to make their own provision. Here, different steps existed in the different coalfields. In the more consensual atmosphere of the north-east of England, the practice of 'smart money' continued, partly as a recognition that disabled miners needed some form of income before compensation was paid. After the passing of the Workmen's Compensation Act in 1897, the Northumberland Coal Owners' Mutual Protection Association issued instructions to members stating that smart money is to be paid to the same classes of men as hitherto, but it is to continue for not more than two weeks. If the disability lasts more than that period then the compensation provided by the Act takes the place of smart money. ${ }^{110}$ The practice of paying 'smart money' continued well into the twentieth century: as late as 1935, the Durham Coal Owners' Mutual Protection Agency insisted that smart money was paid for the first four weeks of disablement prior to the commencement of compensation. ${ }^{111}$ However, smart money was not paid as of right and could be withdrawn or rejected in any individual case. It was also very much confined to the NorthEast; the experience of Coombes confirms that many miners disabled from work had to resort to any combination of the mixed economy of welfare, including the Poor Law.

Compensation payments were never intended to replace lost income, and so they inevitably entailed a significant decrease in the income of the injured or 
sick miner. The Employers' Liability Act limited any compensation payments to the estimated earnings of three years of 'someone in similar employment., ${ }^{12}$ Weekly compensation payments for 'total or partial incapacity for work' under the Workmen's Compensation Act were based on earnings and calculated according to what claimants would have earned before the accident, but were to be 'not exceeding fifty per cent of his average weekly earnings during the previous twelve months, or one pound if the workman had been with the employer for less than one year. ${ }^{113}$ Unsurprisingly, it was found that compensation needed to be supplemented with support from other agencies; as was stated in a House of Commons debate in 1940, 'thousands of men have to seek public assistance to eke out a miserable existence. ${ }^{114}$ Thus, not only did such a system entail a lower level of living after the development of an impairment but it also treated disability solely in terms of lost income and completely neglected the social, cultural and emotional impacts on the disabled miner through its failure to recompense him for the loss of a limb or an impairment of body function.

Impaired miners were faced with yet further difficulties and hardships as a result of the adversarial nature of the compensation system, which pitted them against their employers and gave such employers a financial incentive to contest the extent of disability. Weekly payments were not set in stone and could be reduced or terminated as a result of employer pressure. This was because the extent to which the impairment disabled a miner from working could change over time as the miner's condition changed or, more usually, because the coal company disputed the disabling effect of the impairment and sought revised medical opinions that could be used to reduce or end compensation payments. This was exacerbated by the close relationship that existed between the doctor and the colliery company, which meant that disabled miners were dependent on the medical testimony of their own doctors, who themselves owed their positions to the coal companies and therefore tended to provide expert views that did little to counter the medical testimony provided on behalf of the owners. ${ }^{115}$ In other instances, the disabling impact of impairment could worsen as a miner's condition deteriorated and he would then be forced to seek higher compensation payments from a reluctant employer. In each scenario, the compensation system threw up all manner of obstacles in the way of the miner's securing adequate financial assistance to allow him to cope with his impairment.

Such complexities are best illustrated through individual cases, such as that of Robert Laird, a 'conveyor' in a colliery owned by the Fife Coal Company, who, in 1928, received weekly compensation when a septic wound in his injured hand made him 'totally incapacitated'. He was paid full compensation until a 
medical certificate stated that he was 'fit for any job he could do chiefly with his right hand rendering some assistance from his left'. He 'refused to accept the reduced compensation' and, once returning to work, applied for compensation 'on the footing of total incapacity' based on his hand's being in the same condition, which was refused. Laird's case displays an economic conceptualisation of disability - though one hand was 'incapacitated', the fact that he was able to perform work meant that he was denied full compensation. Though they were unsuccessful, Laird's efforts to receive full compensation highlight the importance that receiving payment meant to those injured. ${ }^{116}$

More complex again was the case of Wittrace Cope, a timber drawer at Houghton Colliery, Durham. Cope's situation also demonstrates the particular difficulties that could arise within the particular arrangements in place in Durham. He suffered a serious accident in 1903 in which he injured his back and hip. He was awarded full compensation at $17 \mathrm{~s}$. $8 \mathrm{~d}$. a week, but payments were ended in 1905 when he was adjudged fit for light work. Cope, it seems, struggled on in his light work despite continued difficulties as a result of his injuries until, in 1918, he brought forward evidence to state that he was unable to work due to the injuries he had received back in 1903 and insisted that he had been declared fit incorrectly. He was awarded compensation again, but only on the condition that he would not try to claim back pay to 1905 . This was regretted by the officers of the Durham Miners' Association, however, and they looked to reopen the case within the Arbitration Committee, despite this not being allowed by the terms of the committee. ${ }^{117}$ Significantly, James Robson, Miners' Agent, set out what he perceived as the injustice meted out too often to disabled miners such as Cope by the compensation system and, in doing so, articulated something of the experience of miners who did not succeed in obtaining compensation for their injuries:

If ever a man suffered a gross injustice at the hands of fellow mortal, Cope has. He has been deprived of his compensation for 13 years, and he has had to bring up his family practically on the Parish. The effect upon a man's general health in having to live under such a great injustice must have been enormous, but to witness his family living under straitened circumstances as compared to what might have been for them under normal circumstances, and to be further deprived of any little assistance he was legally entitled to must have robbed him of any little pleasure he might obtain in life. ${ }^{118}$

Due to the nature of the disease, and the tendency for symptoms to improve as miners were removed from underground work, nystagmus cases were particularly subject to pressures exerted by employers to lessen liability. A number of nystagmus cases that came before the Durham Miners' Association's 
Compensation Committee in 1914, for example, were found to have had their compensation payments reduced after the coal company alleged that the incapacity was at least partially due to causes other than the nystagmus, such as cataracts, detached retinas and other types of 'eye disease. ${ }^{\text {'19 }}$

Coalfields literature picked up on the bitterness that was engendered by the compensation system and offers a scathing view of its inadequacies. Gwyn Thomas is typically sarcastic about the low rates of compensation, describing 'houses where there were to be found voters suffering greatly through the system, from bad lungs or legs, and getting so little compensation one would have thought their lungs and legs had actually improved as a result of being made bad. ${ }^{120}$ Indeed the system - work, pay and conditions - are presented as so poor that miner-characters repeatedly wish for their own deaths in order that their wives might benefit from the larger compensation payout:

NED: Sandy, I'm tired ... I'm no' fit to be workin' doon here, but I've got to do it to keep my wife and weans respectable. (Hopelessly). Ach! there's whiles I wish the roof would come doon on top o' me, and end it ... Mary would get compensation, and her worries would be a' by ... ${ }^{121}$

Another feature of the compensation system that further disadvantaged impaired miners was the practice of lump-sum payments. An amending Workmen's Compensation Act passed in 1906 allowed workers in receipt of compensation the option of receiving lump sums after at least six months of weekly payments, and it was believed that this was an attractive option for some miners. In his 1909 study Accidental Injuries to Workmen, published in reaction to the changes introduced in 1906, the surgeon Henry Norman Barnett maintained that a lump sum was potentially attractive, as 'the workman may be cognisant of his diseased condition and wish to make the most out of his accident to procure a lump sum in order that he may make provision for himself or his family should the disease prevent him from working. ${ }^{122}$

Reasons for wanting a lump sum are explored in fiction, whereby a miner might have a chance of a new life. Sid Chaplin refers, perhaps rosily, to 'a dozen or so little shops which had been started by miners on compensation payments' in a short story in 1946. ${ }^{123}$ The prospects for 'poor Mervyn' in Rhys Davies's Jubilee Blues (1938) include the unconvincing suggestion that 'perhaps he could study to be a chemist,' ${ }^{124}$ but he ultimately leaves the area with his family as part of a government work relocation scheme.

The amount of lump sum paid was very often tied explicitly to the circumstances of a miner's impairment. This is visible in the records of the Scottish Coal Workers' Compensation Scheme, which awarded a number of lump sums based on the consideration of how impairment affected work. The case of Michael Mooney v the Fife Coal Co., for example, concerned a man whose thumb and 
forefinger had been amputated. After a medical examination Mooney was found to be 'practically a one-armed man, whose damaged hand will only act as a guiding agent'. It was these considerations based on the impairment that led the case to settle for up to $£ 200 .{ }^{125}$ Others received lower amounts for reasons related to work and incapacity: Matthew Rutherford, who was 'very anaemic and ill nourished' and had 'poor sight', was found to have 'prospects of life ... below normal, though his other organs appear sound', and thus received $£ 75$. ${ }^{126}$ Thus, opinions on the extent of miners' impairments - almost always connected to the perceived ability to work - dictated levels of compensation.

At the same time, employers attempted to move disabled miners off weekly payments and onto lump-sum payments because it meant a reduction in the amounts paid overall, and trade unions were keen to advise their members not to commute their claims. As Arnold Wilson MP and Hermann Levy stated bluntly in their 1939 study Workmen's Compensation, 'A drowning man clutches at a straw; to an injured workman burdened with debt ... a lump sum, however small, is "popular" only because it offers a temporary respite at the expense of the future. ${ }^{127}$ For his part, James Griffiths, MP for Llanelli in south Wales and later Minister for National Insurance responsible for the passage of the Industrial Injuries Act of 1946, remembered

the tragedy of the 'compo' man of the south Wales valleys, the agents of commercial insurance companies who persuaded injured miners to settle for inadequate sums rather than risk taking employers to court: 'In my village ... there are pathetic cases of industrial casualties left to limp their way through life.' ${ }^{128}$

Whatever the method of claiming or the complexities involved in securing compensation, the very act of collecting compensation could be a demoralising experience. Indeed, it could be made a demoralising experience. Discussing a new Workmen's Compensation Bill in 1933, Mr Tinker, the MP for Leith, told the House of Commons,

When a miner is injured and has established his claim, he has to go to the colliery for his weekly compensation. It is not a pleasant job for the workman. He has to go to the colliery office and sometimes the pay clerk pays it to him, while at other times he has to go and see the manager. That is treating the workman almost as though he were begging something from the employer. ${ }^{129}$

As well as illustrating a manifestation of the power relations between employer and employee, Tinker's comments show the uncertainty and subservience that could go hand in hand with receiving compensation. Indeed, several MPs including Tinker suggested claiming through the Post Office in the same way as pensions were paid, so as to avoid 'the distasteful feeling that he is getting something to which he is not entitled', but this was not successful. ${ }^{130}$ 
Inscribed throughout the compensation system was the fear that workers might be faking injury or disablement in order to receive payments that they did not deserve. Such a fear undoubtedly existed in the minds of employers and doctors but it could also be used for rhetorical and practical effect to minimise compensation payments. Bert Coombes describes a demeaning effect which this culture of suspicion had upon recipients of compensation:

I was paid compensation, but the amount and the method of paying it did not help me to get better. They gave the impression that I was trying to get something for nothing out of them. This compensation was handled by an insurance company, and all the injured were treated as if they had crippled themselves deliberately. ${ }^{131}$

Yet the discourse which divided the injured and disabled into the deserving and undeserving could be adopted by writers generally sympathetic to the workers' cause as a way of representing character. An ex-miner, Joe Corrie, contrasts two claimants in his novel, Black Earth, to show their integrity, or lack of it: 'So while an injury in the pit can mean hell for a man like Jack Smith it could mean Heaven for a man like Ted Jackson.' ${ }^{132}$ Ted Jackson is a bookie, 'a pale-faced little man who walked with a limp', who is genuinely injured in the mine and undergoes surgery, but he exaggerates his injury for a larger compensation pay-out. The morning after the award, 'Ted was able to walk down to the pub without his crutches. A miracle had happened through the night.' ${ }^{133}$

Another group of miners, however, had no recourse to the compensation system and were left with few options for support. Some miners found that the toll of working in the industry caused a general deterioration in health and an accumulation of impairments that could not be attributed to any particular accident or compensatable condition and so did not have access to compensation. Richard Augustine Studdert Redmayne, the resident manager of Seaton Delaval Collieries in Northumberland and a former miner, told the Sankey Commission in 1919:

If a miner is disabled through accident or ill-health occasioned in the mine and proved to have been so occasioned, then he receives compensation under the Compensation Act; but short of that, if a miner, through a breakdown of health, quite apart from that, short of his being on a permanent relief fund or some other fund, of course there is no means of compensating him. ${ }^{134}$

Miners' trade unions were clear in their view that the compensation system failed large sections of the disabled mining population and advocated new forms of welfare which shifted from a narrow, individualistic and legalistic view of industrial disability to a broader, fairer system of welfare that considered health and disability in a more holistic fashion. 
The Workmen's Compensation Act remained active throughout most of the first half of the twentieth century, but the expansion of national state welfare under the post-war Labour government saw it brought to an end. 'The coming of a national scheme for health insurance and, in particular, the passing of the Industrial Injuries Act', wrote the Colliery Guardian in 1948, 'has made the Workmen's Compensation Act, from not a few standpoints, something of a back number. ${ }^{135}$ William Beveridge's 1942 report Social Insurance and Allied Services - the landmark document of the conception of the welfare state - had highlighted the shortfalls of the existing compensation system, which was 'below subsistence level for anyone who had family responsibilities or whose earnings in work were less than twice the amount needed for subsistence. ${ }^{136}$ The Workmen's Compensation Act was finally replaced by the National Insurance (Industrial Injuries) Act of 1946, passed by the former miners' leader, Jim Griffiths. It provided the first insurance-based compensation system for injured workers, taken from a fund contributed to by workers, employers and the state, and instituted more generous compensation payments than workers had received previously. ${ }^{137}$ It was a recognition of the decades of support given to the Labour Party by the miners' trade unions and the importance of compensation to union politics and the lives of miners.

\section{Conclusion}

The period after 1880 saw the first legislation which recognised the principles of employers' liability and workers' rights to compensation, in a direct reaction to an economy of welfare which made it extremely difficult for disabled miners to attain any sense of financial security, even though they were supposedly statutorily entitled to it. The Employers' Liability Act and the Workmen's Compensation Act both contributed to a shift in attitudes towards the responsibility of employers and the disabled miner's right to compensation, but the actual process of claiming compensation was long and flawed, and rarely ended in a desirable amount being awarded. Disabled miners in the late nineteenth century and the first half of the twentieth - even those receiving compensation - had to rely on multiple sources of welfare from an unco-ordinated tapestry of voluntary and state organisations.

Furthermore, even though the principle of collective compulsory welfare was emerging, the principles of routine surveillance, unsteady payment and implied moral responsibility for impairment were visible in almost all of these welfare sources. Friendly societies and permanent relief funds, though declining, remained active, and the waning Poor Law was still turned to, largely as a last resort in cases of emergency. Likewise, existing domestic support networks 
based around family and community were crucial to miners who could not survive by relying solely on organisations. Literary representations of welfare and compensation tended to be influenced by the class alliances of the author. The interwar fiction by working-class writers focuses on the injustices and humiliations of unfair systems in contrast to the willingness of communities to help out injured miners with 'lifts', yet some also expressed anxieties about malingering. Undoubtedly, this period saw disease and injury in mining communities being reframed away from an individualised tragedy which could be addressed only through self-help or the stigmatised Poor Law, and towards an interpretation of disability as something that could be the fault of the employer and thus compensated. However, the need to rely on multiple forms of welfare and subsistence continued long after this change in the conceptualisation of disability came about, and dependency came to form the main experience of impaired miners.

\section{Notes}

1 For overviews, see Derek Fraser, The Evolution of the British Welfare State: A History of Social Policy since the Industrial Revolution, 3rd edn (Basingstoke: Palgrave Macmillan, 2003); David Gladstone, The Twentieth-Century Welfare State, British History in Perspective (Basingstoke: Macmillan, 1999); Alan J. Kidd, State, Society and the Poor in Nineteenth-Century England, Social History in Perspective (Basingstoke: Macmillan, 1999); Bernard Harris, The Origins of the British Welfare State: Society, State and Social Welfare in England and Wales, 1800-1945 (Basingstoke: Palgrave Macmillan, 2004).

2 The changing portrayal of welfare was further reflected in the class and political affiliation of the writer, as working-class writers (many former miners, often with strong political ties to trade unions or to the International Labour Party/Labour Party) sought to show various ways in which the systemic inequality of wealth and power kept working-class people in constant risk of poverty and exposed to an unacceptably high probability of ill-health or injury.

3 Jose Harris, cited in Fraser, The Evolution of the British Welfare State, p. 13.

4 Laura E. Marshak, Milton Seligman and Fran Prezant, Disability and the Family Life Cycle (New York: Basic Books, 1999), pp. 9-10; Jane Lewis, 'Family Provision of Health and Welfare in the Mixed Economy of Care in the Late Nineteenth and Twentieth Centuries', Social History of Medicine, 8:1 (1995), pp. 1-16.

5 Glamorgan Archives (hereafter GA), D/D Vau 20, 'A Friend in Need is a Friend Indeed'; Tarian y Gweithiwr, 25 May 1899, p. 1.

6 T. Rowland Hughes (1903-49) was born in Llanberis, Caernarvonshire, the son of a quarryman, and worked as a university lecturer, and producer of Welsh feature programmes for the BBC. He was diagnosed with multiple sclerosis in 1937 and 
during this period was a successful Welsh-language poet (twice winning the Chair of the National Eisteddfod, in 1937 and 1940) and novelist, producing a novel a year from 1943 to 1947.

7 T. Rowland Hughes, William Jones (Llandysul: Gwasg Gomer, 1991), p. 356.

8 T. Rowland Huges, trans. Richard Ruck, William Jones (Aberystwyth: Gwasg Aberystwyth, 1953), p. 288.

9 James Welsh, The Underworld (London: Herbert Jenkins, 1920), p. 19.

10 Welsh, The Underworld, p. 20.

11 Durham County Record Office (hereafter DCRO), CC/X 140, Minutes for Lord Mayor of London's Mining Distress Fund (later the Coalfields Distress Funds), Northern Coalfields Committee, 14 February 1929.

12 West Glamorgan Archives Service, D/D SHF/1, Swansea Hospital Ladies' Samaritan Fund Minute Book, Monthly Meeting, 12 September 1913.

13 National Archives of Scotland (hereafter NAS), Scottish Coal Workers' Compensation Scheme, Director's Minute Books, 1912-1914, F 148/12, John Black v. The Fife Coal Co Ltd.

14 DCRO, D/DMA (Acc: 1004(D)) 167, Durham Miners' Association Compensation Department Monthly Reports, 1918-1919, p. 16.

15 Lewis, 'Family Provision of Health and Welfare in the Mixed Economy of Care'.

16 Mike Mantin, 'Philanthropy and Deafness in Wales, 1847-1914', Welsh History Review, 27:2 (2014), p. 289.

17 Blind Persons Act (1920); GA, DBLI/RH/1, Minute Book, Management Committee Meeting, 9 September 1920.

18 GA, DBLI/RH/2, Minute Book, Special General Committee Meeting, 22 April 1925. The 'Conditions of Service' document was attached to the minutes, and thus was written before the meeting took place.

19 For examples, see Mary Wilson Carpenter, Health, Medicine, and Society in Victorian England (Santa Barbara: Praeger, 2010); Colin Lees and Sue Ralph, 'Charitable Provision for Blind People and Deaf People in Late Nineteenth Century London', Journal of Research in Special Educational Needs, 4:3 (2004), pp. 148-60.

20 GA, DBLI/RH/15, Minute Book, Management Committee Meeting, 8 September 1947.

21 GA, DBLI/RH/1, Minute Book, Management Committee Meeting, 9 September 1920; GA, DBLI/RH/5, Minute Book, Management Committee Meeting, 30 November 1931.

22 GA, DBLI/RH/2, Minute Book, Management Committee Meeting, 16 May 1927.

23 See David M. Turner and Daniel Blackie, Disability in the Industrial Revolution: Physical Impairment in British Coalmining, 1780-1880 (Manchester: Manchester University Press, 2018).

24 DCRO, D/EBF 92/13, Rules of the Durham County Enginemen's, Boiler Minders' and Firemen's Mutual Aid Association and National Insurance Approved Society, 1913. 
25 DCRO, D/X, 411/110, Revised Rules of the Tradesmen's Annual Friendly Society, 1885.

26 P. H. J. H. Gosden, The Friendly Societies in England 1815-1875 (London: Batsford, 1973), pp. 82-4.

27 The National Archives, London (hereafter TNA), FS 15/842, Aberaman Colliery Friendly Society, Rules of the Aberaman Colliery Friendly Society, 1892.

28 For example, members of the Durham County Colliery Enginemen's Mutual Protection Association were fined up to $£ 1$ for being 'detected imposing in this way' TNA, FS 28/6, Durham Colliery County Enginemen’s Mutual Protection Association, Rules, 1883.

29 TNA, FS 15/847, Llanbradach Colliery Sick Benefit Society, 1895-1915, Rules of the Llanbradach Colliery Sick Benefit Society, 1905.

30 Swansea University, South Wales Coalfield Collection, MNA/NUM/I/34/165, Rules of the Glais Benefit Society, 1871.

31 DCRO, D/EBF 92/13, Rules of the Durham County Enginemen's, Boiler Minders' and Firemen's Mutual Aid Association and National Insurance Approved Society, 1913.

32 DCRO, D/IOR 57, North Eastern Counties Friendly Societies Convalescent Home, Rules of the North Eastern Counties Friendly Societies' Convalescent Home, 1893.

33 Harry Lindsay, Rhoda Roberts: A Welsh mining story (London: Chatto \& Windus, 1895), p. 112.

34 John Benson, 'Coalminers, Coalowners and Collaboration: The Miners' Permanent Relief Fund Movement in England, 1860-1895', Labour History Review, 68:2 (2003), pp. 181-94.

35 George L. Campbell, Miners' Thrift and Employers' Liability (Wigan: Strowger and Son, 1891), pp. 6-7.

36 George L. Campbell, Miners' Insurance Funds: Their Origin and Extent (London: Waterlow \& Sons, 1880), pp. 9-11.

37 Harold Heslop, The Earth Beneath (London: T. V. Boardman \& Company Ltd., 1946), p. 161.

38 Campbell, Miners' Insurance Fund, pp. 6-7.

39 DCRO, NCBI/RS/1469, Draft of the Rules of the Miners' Provident Association, 1859; Tyne and Wear Archives Service (hereafter TWAS), CH.MPR/14/1 (MF2196), Miners' Disablement Fund (1863-1891); Turner and Blackie, Disability in the Industrial Revolution, pp. 99-100.

40 TWAS, CH.MPR/14/1 (MF2196), Miners' Disablement Fund (1863-1891).

41 Campbell, Miners' Thrift and Employers' Liability, p. 11.

42 TWAS, CH/MPR/10/1, Northumberland and Durham Miners Permanent Relief Fund, Rules, 1899, Rules 36 and 37; TWA, CH/MPR/10/5, Northumberland and Durham Miners' Permanent Relief Fund, Rules, 1923, Rules 37 and 38.

43 Cardiff Central Library, Monmouthshire and South Wales Miners' Permanent Provident Society, Report of Proceedings at the 2nd Annual General Meeting, 27 
March 1883, p. 13; Report of Proceedings at the 21st Annual General Meeting, 25 March 1902, p. 18.

44 John Benson 'Non-Fatal Coalmining Accidents', Bulletin of the Society for the Study of Labour History, 32 (1976), p. 22.

45 Benson, 'Coalminers, Coalowners and Collaboration', p. 186.

46 Monmouthshire and South Wales Miners' Permanent Relief Society, Report of the Fourth Annual Meeting, March 31st, 1885, pp. 6-7.

47 Monmouthshire and South Wales Miners' Permanent Relief Society, 'Report of the Board of Management', Report of the Fifth Annual Meeting, March 30th, 1886, p. 17.

48 TWAS, CH/MPR/10/1, Northumberland and Durham Miners' Permanent Relief Fund, Rules, 1899.

49 TWAS, CH/MPR/1/7, Northumberland and Durham Miners' Permanent Relief Fund, Committee Minutes, Minutes of the General Committee Meeting, 22 September 1906.

50 Cardiff Central Library, Monmouthshire and South Wales Permanent Provident Society, Annual Reports, 1881-1893, Report of proceedings at the 3rd Annual General Meeting, 23 June 1884.

51 Benson, 'Colaminers, Coalowners and Collaboration', p. 18; Royal Commission on the Poor Laws and Relief of Distress, Appendix volume V, Minutes of Evidence (90th to 94th days) with Appendix, Cd. 4888, 1909, xli, p. 203.

52 Royal Commission on the Poor Laws and Relief of Distress, Appendix volume V, Minutes of Evidence (90th to 94th days) with Appendix, Cd. 4888, 1909, xli, p. 203.

53 Poor Law Amendment Act 1834, cited in Kenneth Morgan, The Birth of Industrial Britain: Social Change 1750-1850 (Harlow: Pearson, 2004), p. 134. While the principle of 'less eligibility' was not enshrined in the Poor Law Amendment (Scotland) Act of 1845, Poor Law authorities north of the border introduced a poorhouse test into practice as a means to distinguish between deserving and underserving claimants for relief; see Stephanie Blackden, 'The Board of Supervision and the Scottish Parochial Medical Service, 1845-95', Medical History, 30:2 (1986), p. 147. See also Audrey Paterson, 'The Poor Law in Nineteenth-Century Scotland', in Derek Fraser (ed.), The New Poor Law in the Nineteenth Century (London: Macmillan, 1976), pp. 171-93.

54 See, for example, David Gladstone, The Twentieth-Century Welfare State (Basingstoke: Macmillan, 1999), p. 12; Lauren M. E. Goodlad, "'Make the Working Man Like Me”: Charity, Pastorship and Middle-Class Identity in Nineteenth-Century Britain: Thomas Chalmers and Dr James Phillips Kay', Victorian Studies, 43:4 (2001), p. 592.

55 Deborah Stone, The Disabled State (Basingstoke: Macmillan, 1985), p. 40.

56 Stone, Disabled State, p. 51.

57 Anne Borsay, Disability and Social Policy: A History of Exclusion (Basingstoke: Palgrave Macmillan, 2005), p. 152. 
58 David M. Turner, “"Fraudulent” Disability in Historical Perspective', History and Policy (2012), http://www.historyandpolicy.org/papers/policy-paper-130.html, accessed 5 January 2013.

59 Hugh Gilmore, The Black Diamond (London: Thomas Mitchell Primitive Methodist Publishing House, 1880), pp. 19-20.

60 Harold Heslop, The Gate of a Strange Field (New York: D. Appleton \& Company, 1929), p. 135.

61 Heslop, The Gate of a Strange Field, p. 147.

62 James Welsh, The Morlocks (London: Herbert Jenkins Ltd, 1924), p. 45.

63 Tom Hanlin, Once in Every Lifetime (New York: The Viking Press, 1945), p. 173.

64 Elizabeth Andrews, A Woman's Work Is Never Done: Being the Recollections of a Childhood and Upbringing amongst the South Wales Miners and a Lifetime of Service to the Labour Movement in Wales (Rhondda: Cymric Democrat Publishing Society, 1957), p. 12.

65 Ministry of Health Act (1919).

66 Local Government Act (1929); Harris, The Origins of the British Welfare State, p. 203.

67 Generally, the Poor Law in Scotland tended to be less generous than that in England and Wales, and divergence in practice widened as the nineteenth century progressed; see M. A. Crowther, 'Poverty, Health and Welfare', in W. Hamish Fraser and R. J. Morris (eds), People and Society in Scotland: Volume II, 1830-1914 (Edinburgh: John Donald Publishers Ltd, 1990), pp. 268-9.

68 Local Government Board, Eighteenth Annual Report of the Local Government Board, C. 5813, 1889, pp. xxxv, lxxvi-lxxvii.

69 Blackden, 'The Board of Supervision and the Scottish Parochial Medical Service', pp. 148, 161, 163-6; see also Crowther, 'Poverty, Health and Welfare', p. 275.

70 Seventeenth Annual Report of the Ministry of Health, 1935-36, Cmd. 5287, 1935-36, x, p. 121; Seventh Annual Report of the Department of Health for Scotland, 1935, Cmd. 5123, 1935-36, xi, p. 140.

71 Heslop, The Gate of a Strange Field, p. 135.

72 Mitchell Library, Glasgow City Archives (hereafter ML), C01 39/53, Douglas Parochial Board Record of Applications, 24 September 1885.

73 ML, D-HEW 17/297/1, Applications for Relief, Govan Parish, 25 August 1896.

74 ML, CO1 27/92, Applications for relief, Carluke, 1878-83; ML, CO1 27/93, Applications for relief, Carluke, 1884-93.

75 Gwent Archives, CSWBGB/C/29, Bedwellty Union Out Relief Advisory Committee Papers, 18 February 1924.

76 Gwent Archives, CSWBGB/C/29, Bedwellty Union Out Relief Advisory Committee Papers, 18 February 1924; see also Blackden, 'The Board of Supervision and the Scottish Parochial Medical Service', p. 161.

77 NAS, GD 176/1959, Circular letter as to the use of the Poorhouse as a test, Board of Supervision, Edinburgh, 26th July, 1883; for an example, see Gwent Archives, CSWBGB/C/29, Bedwellty Union Out Relief Advisory Committee Minutes, 3 July 1929. 
78 Gwent Archives, CSW/BGP/I/222-230, Pontypool Union Workhouse Admissions and Discharges, $1858-1935$.

79 DCRO, U/EA 24, Easington Union Relief Committee Minutes, 30 November 1898-7 February 1912, 6 April 1910.

80 Glasgow Herald, 11 December 1911.

81 John Benson, 'Poor Law Guardians, Coalminers, and Friendly Societies in Northern England, 1860-1894: Statutory Provision, Local Autonomy, and Individual Responsibility', Northern History, 44:2 (2007), p. 160.

82 Northumberland Archives (hereafter NA), CC/CM/PA/1, County of Northumberland Public Assistance Committee Minutes, 2 December 1929-2 January 1935, 11 June 1930.

83 P. W. J. Bartrip, Wounded Soldiers of Industry: Industrial Compensation Policy 1833-1897 (Oxford: Clarendon Press, 1983).

84 Employers' Liability Act (1880).

85 P. W. J. Bartrip, Workmen's Compensation in Twentieth Century Britain: Law, History and Social Policy (Aldershot: Gower, 1987).

86 Peter Bartrip, 'The Rise and Decline of Workmen's Compensation', in Paul Weindling (ed.), The Social History of Occupational Health (London: Croom Helm, 1985), pp. 157-79.

87 TWAS, CH/MPR/10/8, Northumberland and Durham Miners' Permanent Relief Fund, Rules, 1938.

88 Labour Leader, 20 August 1898.

89 Cardiff Library, Monmouthshire and South Wales Permanent Provident Society, Annual Reports 1906-1920, Report of proceedings at the 28th Annual General Meeting, 30 March 1909; Monmouthshire and South Wales Miners' Permanent Provident Society, Annual Report, 1920, p. 15.

90 Workmen's Compensation (War Addition) Act, 1917; Workmen's Compensation (War Addition) Act, 1919; Colliery Guardian, 2 January 1920; Bartrip, Workmen's Compensation in Twentieth Century Britain.

91 William Beveridge, Social Insurance and Allied Services, Cmd. 6404 (1942); Report of the Royal Commission on Workmen's Compensation, Cmd. 6588 (London: HMSO, 1945).

92 Angela Turner and Arthur McIvor, “Bottom Dog Men” : Disability, Social Welfare and Advocacy in the Scottish Coalfields in the Interwar Years, 1918-1939', Scottish Historical Review, 96:2 (2017), p. 209.

93 On the differences in industrial relations in the different coalfields, see Stefan Berger, Andy Croll and Norman LaPorte (eds), Towards a Comparative History of Coalfield Societies (Aldershot: Ashgate, 2005); Alan Campbell, Nina Fishman and David Howell (eds), Miners, Unions and Politics, 1910-47 (Aldershot: Ashgate, 1996); John McIlroy, Alan Campbell and Keith Gildart (eds), Industrial Politics and the 1926 Mining Lockout: The Struggle for Dignity (Cardiff: University of Wales Press, 2004); on the Arbitration Committee, see W. R. Garside, The Durham Miners 1919-1960 (London: George Allen \& Unwin Ltd, 1971), pp. 308-10. 
94 Departmental Committee on Workmen's Compensation, Minutes of Evidence, Volume1, [Cmd. 908], 1920, xxvi, p. 242, para.5952.

95 North East Mining Archive and Research Centre (hereafter NEEMARC), NUMDA/6/1/1/1, DMA Reports of the Compensation Department, Volume I, Arbitration Committee, 3 March 1919.

96 DCRO, D/DMA Acc 1004 D 169, Durham Miners' Association, Review of the Work of the Compensation Department for the year 1922, p. 355.

97 DCRO, D/DMA Acc 1004 D 169, Durham Miners' Association, Review of the Work of the Compensation Department for the year 1922, p. 358; see also, DCRO, D/DMA Acc 1004 D 169, Durham Miners' Association, Review of the Work of the Compensation Department during the year 1925, p. 488.

98 DCRO, D/DMA Acc 1004 D 169, Durham Miners' Association, Review of the Work of the Compensation Department during the year 1925, p. 488.

99 Joanna Bourke. Dismembering the Male: Men's Bodies, Britain and the Great War (London: Reaktion, 1999), p. 48.

100 There was a similar suspicion towards the judiciary about enquiries into accidental deaths in mining. See B. L. Coombes, These Poor Hands: The Autobiography of a Miner Working in South Wales, with an Introduction by Bill Jones and Chris Williams (Cardiff: University of Wales Press, 2002) or Lewis Jones's Cwmardy in Lewis Jones, Cwmardy and We Live (Cardigan: Parthian, 2006).

101 Hughes, William Jones, p. 139.

102 Hughes, trans. Ruck, William Jones, p. 93.

103 For example, Rhys Davies's short story, 'The Pits Are on the Top', in Rhys Davies, Collected Stories: Volume I, edited by Meic Stephens (Llandysul: Gomer Press, 1996) pp. 261-6, involves a miner who had just died from lung disease, but had not received compensation because he was diagnosed with bronchitis.

104 Discussed further in Chapter 6.

105 A. J. Cronin, Adventures in Two Worlds (London: Victor Gollancz, 1952), pp. 159-60.

106 A. J. Cronin, The Citadel (London: Vista, 1996), p. 117.

107 Cronin, The Citadel, p. 119.

108 Employers' Liability Act, 1880; Workmen's Compensation Act, 1897.

109 Coombes, These Poor Hands, p. 63.

110 NA, NRO 00263/C/1/2/1, Northumberland Coal Owners' Mutual Protections Association, Minute Book, Workmen's Compensation Act, 1897, Instructions to Members.

111 DCRO, D/DCOMPA 208, Durham Coal Owners' Mutual Protection Association, Workmen's compensation Acts: Instructions to Members, May 1935.

112 Employers' Liability Act, 1880.

113 Workmen's Compensation Act, 1897.

114 Hansard, 30 January 1940.

115 DCRO, D/DMA Acc 1004 D 169, Durham Miners' Association, Review of the Work of the Compensation Department during the year 1924, pp. 869-70. 
116 NAS, SC21/12A/1928/18, Robert Laird v The Fife Coal Company, Dunfermline Sherriff Court, 18 September 1928 and 8 November 1928.

117 DCRO, D/DMA 167, Durham Miners' Association, Compensation Department Monthly Reports, September 1918-December 1919.

118 DCRO, D/DMA 167, Durham Miners Association, Compensation Department Monthly Reports, Report for October 1918, p. 21.

119 NEEMARC, NUMDA/1/6/39, Durham Miners' Association Compensation Committee Minutes, 1914.

120 Gwyn Thomas, The Dark Philosophers (Cardigan: Parthian, 2006 [1946]), p. 206.

121 Joe Corrie, 'Hewers o' Coal', in Joe Corrie, Plays Poems \& Theatre Writings, Linda MacKenney (ed.) (Edinburgh: 7:84 Publications, 1985), p. 109. See also John Swan's The Mad Miner (London: The Houghton Publishing Company, 1933), p. 151 and Gwyn Thomas, "Oscar", in Where Did I Put My Pity? (London: Progress Publishing Company, 1946), p. 34.

122 Henry Norman Barnett, Accidental Injuries to Workmen: With Reference to Workmen's Compensation Act, 1906. With Article on Injuries to the Organs of Special Sense (London: Rebman, 1909), p. 114.

123 Sid Chaplin, 'Half Moon Street', in Geoffrey Halson (ed.), The Leaping Lad and other stories (Harlow: Longman Group Ltd., 1970 [1946]), p. 19.

124 Rhys Davies, Jubilee Blues (London: Heinemann, 1938), p. 213.

125 NAS, Scottish Coal Workers' Compensation Scheme, Director's Minute Books, 1912-1914, F3235/14, Michael Mooney v The Fife Coal Co. Ltd.

126 NAS, Scottish Coal Workers' Compensation Scheme, Director's Minute Books, 1912-1914, F287/13, Rutherford v The Fife Coal Co. Ltd.

127 Arnold Talbot Wilson and Hermann Levy, Workmen's Compensation (London: Oxford University Press, 1939), p. 134.

128 James Griffiths, Pages from Memory (London: J. M. Dent \& Sons Ltd., 1969), p. 82 .

129 Hansard, 10 February 1933.

130 Hansard, 10 February 1933.

131 Coombes, These Poor Hands, p. 63.

132 Joe Corrie, Black Earth (London: Routledge, 1939), p. 233.

133 Corrie, Black Earth, p. 232.

134 Coal Industry Commission, Vol. II: Reports and Minutes of Evidence on the First Stage of the Inquiry, Cmd. 360 (London: HMSO 1919), p. 1163.

135 Colliery Guardian, 11 June 1948.

136 Beveridge, Social Insurance and Allied Services, p. 7.

137 Bartrip, Workmen's Compensation in Twentieth Century Britain; McIvor and Johnston, Miners' Lung, p. 203. 